\title{
Evaluation of heating temperature and time on bending properties of Taurus cedar wood
}

\author{
Tuğba Yılmaz Aydına,* (i)
}

\begin{abstract}
Heat treatment is one of the environmentally friendly and cost-effective modification methods applied for improvements of wood properties. However, influences of exposure duration and temperature should be known to provide balanced improvements for properties. In this study, effect of temperature $\left(80,120,150,180\right.$, and $\left.210^{\circ} \mathrm{C}\right)$ and exposure duration $(2,5$, and $8 \mathrm{~h})$ on the longitudinal ultrasonic wave velocity, density, dynamic Modulus of Elasticity-MOE $\left(E_{\mathrm{dyn}}\right)$, MOE in bending, and Modulus of Rupture (MOR) properties of Taurus cedar (Cedrus libani) was figured out. $E_{\mathrm{dyn}}$ was predicted using ultrasonic wave velocity of 2.25 MHz longitudinal ultrasonic wave propagated through the longitudinal axis. The three-point bending test was performed to determine static mechanical properties. According to results, the highest adverse effects of extended duration and temperature were observed for MOR and followed by $E_{\mathrm{dyn}}$, and MOE in bending. Up to $150^{\circ} \mathrm{C}$ and $8 \mathrm{~h}$ treatment levels, some remarkable increases $(15.3 \%)$ were observed particularly for MOE in bending. Coefficients of determinations were calculated as $0.83,0.38$, and 0.37 for $E_{\mathrm{dyn}} \mathrm{Vs} \mathrm{MOE}$ in bending, $E_{\mathrm{dyn}} \mathrm{vs}$ MOR, and MOE in bending vs MOR, respectively.

Keywords: Cedar, Ultrasound, Modulus of elasticity, Modulus of rupture
\end{abstract}

\section{Toros sediri odununun eğilme özellikleri üzerine ısıtma sıcaklığı ve süresinin değerlendirilmesi}

\begin{abstract}
Özet: Isıl işlem, ağaç malzeme özelliklerinin geliştirilmesinde kullanılan çevre dostu ve uygun maliyetli modifikasyon yöntemlerinden biridir. Fakat özelliklerde dengeli iyileşmeler sağlayabilmek için sıcaklık ve işlem süresi etkilerinin bilinmesi gereklidir. Bu çalışmada, sıcaklık $\left(80,120,150,180\right.$ ve $\left.210^{\circ} \mathrm{C}\right)$ ve işlem süresinin $(2,5$ ve 8 saat) Toros sediri (Cedrus libani) odununda boyuna ultrasonik dalga hızı, yoğunluk, dinamik elastikiyet modülü ( $E_{\text {dyn }}$ ), eğilmede elastikiyet modülü ve eğilme direnci üzerine etkisi incelenmiştir. $E_{\mathrm{dyn}}$ lif doğrultusunda yayınım gerçekleştirilen $2.25 \mathrm{MHz}$ frekanslı boyuna ultrasonik dalganın ses hızı ile tahmin edilmiştir. Üç nokta eğilme testi ile statik mekanik değerler belirlenmiștir. Sonuçlara göre yoğun işlem süresi ve sıcaklığın olumsuz yönde en yüksek etkisi eğilme direncinde görülmüş ve bunu dinamik ve statik elastikiyet modülleri takip etmiştir. $150^{\circ} \mathrm{C}^{\prime}$ ye kadar ve 8 saatlik işlem seviyelerinde, özellikle eğilmede elastikiyet modülü için bazı kayda değer iyileşmeler (\%15.3) görülmüştür. $E_{\mathrm{dyn}}$ ile eğilmede elastikiyet modülü, $E_{\mathrm{dyn}}$ ile eğilme direnci ve eğilmede elastikiye modülü ile eğilme direnci arasındaki determinayson katsayıları sırası ile $0.83,0.38$ ve 0.37 olarak hesaplanmıştır.

Anahtar kelimeler: Sedir, Ultrases, Elastikiyet modülü, Eğilme direnci
\end{abstract}

\section{Introduction}

Wood, as a natural and renewable bio-material, is one of the commonly used constructions and building materials. Wood has some significant physical and mechanical properties. However, dimensional instability, photo, and biodegradation, burning, etc. are some of the significant disadvantages of wood materials that vary in terms of species. Different modification methods are being used to reduce or eliminate such undesired properties of wood materials, and heat-treatment is one of these techniques. Heat-treatment came into the forefront due to its cost-effectiveness and environmental friendliness against costly and timeconsuming chemical methods (Chien et al. 2018). In the heattreatment process, from 100 to $300^{\circ} \mathrm{C}$ and up to $24 \mathrm{~h}$ temperatures and exposure durations are utilized for thermal wood modification (Gennari et al. 2021). Wood loses free and bounded water when exposed to temperatures up to $150{ }^{\circ} \mathrm{C}$. However, exposure beginning from 180 to $250{ }^{\circ} \mathrm{C}$ temperatures causes significant chemical transformations, and carbonization occurs above $250^{\circ} \mathrm{C}$ (Esteves and Pereira 2009). There is an interrelation between the exposure duration and temperature, and indeed, the effect of temperature increases with the increase in exposure duration particularly for high-temperature levels.

When literature was reviewed, the effect of heattreatment on the properties of Taurus cedar was studied in a limited manner. Ayata and Bal (2019) evaluated the influences of microbiologically active soil (around 16 weeks exposure) on the heat-treated $\left(140,170\right.$, and $200^{\circ} \mathrm{C}$ for $2 \mathrm{~h}$ ) Taurus cedar, and stated that heat treatment advanced the biological resistance. Bal (2016a) determined the influences of hot $\left(160,180,200\right.$, and $\left.220{ }^{\circ} \mathrm{C}\right)$ oil treatment on some physical properties of Taurus cedar, and stated that
Isparta University of Applied Sciences, Faculty of Forestry, Forest Products Engineering, Isparta, Turkey

@ * Corresponding author (İletişim yazarı): tugbayilmaz@ isparta.edu.tr

$\checkmark \quad$ Received (Geliş tarihi): 04.11.2021, Accepted (Kabul tarihi): 09.12.2021
Citation (Atıf): Yılmaz Aydın, T., 2021. Evaluation of heating temperature and time on bending properties of Taurus cedar wood. Turkish Journal of Forestry, 22(4): 432-438. DOI: $10.18182 /$ tjf.1019032 
dimensional stabilization improved with this modification. Bal (2013) evaluated the effect of heat-treatment (140, 160, 180,200 , and $220^{\circ} \mathrm{C}$ ) on density, MC, volumetric swelling, thickness swelling in radial and tangential directions, mass loss, equilibrium MC for heart and sapwood of Taurus cedar. Nabil et al. (2018) evaluated the effect of heat treatment (160, 180,200 , and $220^{\circ} \mathrm{C}$ for 2,4 , and $6 \mathrm{~h}$ ) on MOR, CS, mass loss, and color change for Taurus cedar. The authors stated that MOR and CS were steadily decreased with the increase in temperature and duration. Kilınçarslan et al. (2020) used ANN and random forest algorithm to predict swelling and shrinkage of commercially obtained heat-treated Taurus cedar.

Even defect detection is one of the most widespread applications, strength, and elastic parameter determinations are successfully applied inspection field of ultrasonic testing and evaluation (Senalik et al. 2014). And, following studies dealt with the evaluation of cedar (particularly Japanese) properties. Chen et al. (2014) evaluated the effect of thinning on ultrasonic wave velocities $\left(\mathrm{V}_{\mathrm{LL}}\right.$ and $\left.\mathrm{V}_{\mathrm{RR}}\right)$ and dynamic $\operatorname{MOE}\left(E_{\mathrm{dyn}}\right)$ standing Japanese cedar trees using $22 \mathrm{kHz}$ ultrasonic wave. Thinning-related $\mathrm{V}_{\mathrm{LL}}, \mathrm{V}_{\mathrm{RR}}$, and $E_{\mathrm{dyn}}$ were ranged from 2665 to $2879 \mathrm{~m} / \mathrm{s}, 1477$ to $1643 \mathrm{~m} / \mathrm{s}$, and 1053 to $1363 \mathrm{MPa}$, respectively. The authors stated that there were no statistically significant differences between the thinning and determined properties. Chuang and Wang (2001) predicted the $E_{\mathrm{dyn}}$ of standing Japanese cedar using $16 \mathrm{kHz}$ ultrasound (US) propagation. Yeh et al. (2007) compared the $E_{\text {dyn }}$ (determined using 0.02, 0.04, 0.1, 0.2, 0.5, and $1 \mathrm{MHz}$ frequency longitudinal ultrasonic wave propagated by direct, semi-direct, and surface transmission methods) and static MOE ( 3 points bending) and thinned logs of Japanese cedar. The authors reported $\mathrm{V}_{\mathrm{LL}}$ values ranged from 4882 to 5196 $\mathrm{m} / \mathrm{s} \mathrm{V}_{\mathrm{LL}}$ corresponding to 0.04 and $0.2 \mathrm{MHz}$ frequencies in the direct method, respectively. Furthermore, it's reported that using flat transducers with coupling agents provided higher values which were statistically significant. A strong relationship ( $\mathrm{R}^{2}$ : 0.855$)$ between $E_{\mathrm{dyn}}$ and UWV (for direct method) was also reported. Chiu et al. (2013) measured the $\mathrm{V}_{\mathrm{LL}}$ for the calculation of $E_{\mathrm{dyn}}$ for standing Taiwan incense cedar using $22 \mathrm{kHz}$ frequency and compared with static MOE determined by 3 points bending test. The longitudinal ultrasonic wave was propagated through north-south and east-west directions and different height positions of standing trees. The authors reported that static MOE is lower than $E_{\mathrm{dyn}}$. Hasegawa et al. (2011) evaluate the effect of tracheid length and microfibril angle on ultrasonic wave velocity $(500 \mathrm{kHz}$ frequency) in Japanese cedar, and reported strong correlations between variables. Wang et al. (2008) determined $\mathrm{V}_{\mathrm{LL}}(2366$ and $2677 \mathrm{~m} / \mathrm{s})$ and calculated $E_{\mathrm{dyn}}$ (2624 and $3466 \mathrm{MPa}$, respectively) for Japanese cedar using $22 \mathrm{kHz}$ frequency. Hasegawa et al. (2016) determined $\mathrm{V}_{\mathrm{LL}}$ (ranged from 3468 to $3964 \mathrm{~m} / \mathrm{s}$ ) for Japanese cedar using noncontact air-coupled ultrasonic wave propagation $(200 \mathrm{kHz})$. The $\mathrm{V}_{\mathrm{LL}}$ were around 4126,4310 , and $4950 \mathrm{~m} / \mathrm{s}$ when contact type transducers with $0.2,0.5$, and $2.5 \mathrm{MHz}$ frequencies were used, respectively. Oh et al. (2011) used longitudinal ultrasonic wave propagation to evaluate the sorting of Japanese cedar logs by comparing the $E_{\text {dyn }}$ predicted using a grading tool. Apart from the above-mentioned studies, the followings are the few studies that evaluated the Taurus cedar properties using US. Yilmaz Aydın and Aydın (2018a) evaluated the effect of density and propagation length on ultrasonic wave velocity. Güntekin and Yılmaz Aydın (2016) determined $\mathrm{V}_{\mathrm{LL}}$, static and $E_{\mathrm{dyn}}$ and MOR for around $12 \%$ MC. The authors performed 3 point bending test to determine static MOE and MOR, and longitudinal ultrasonic wave (2.25 $\mathrm{MHz}$ ) propagation. Güntekin et al. (2016) predicted some elastic constants using $1 \mathrm{MHz}$ shear wave propagation. Güntekin et al. (2015a; b) predicted moisture induced dynamic and static MOE of Taurus cedar using US $(22 \mathrm{kHz})$ propagation and compression test, respectively. Güntekin et al. (2015) evaluated the effect of moisture on $\mathrm{V}_{\mathrm{LL}}$, static and $E_{\mathrm{dyn}}$, and Young's modulus for Taurus cedar wood. However, effect of temperature and exposure duration on some physical and mechanical properties of Taurus cedar wood was not evaluated using both non-destructive and destructive tests. Therefore, this study aimed to figure out this issue using US measurements and comparison with static values

\section{Materials and methods}

Taurus cedar (Cedrus libani) timber was purchased from a commercial company. Air-dried defect-free cedar samples $(22 * 70 * 350 \mathrm{~mm})$ were exposed to five different temperatures $\left(80,120,150,180\right.$, and $\left.210^{\circ} \mathrm{C}\right)$ for three different times $(2,5$, and $8 \mathrm{~h}$ ). A laboratory furnace FN 500 (Nüve Co., Ankara, Turkey) was used in ambient air. Nondestructive test samples $(20 * 20 * 20 \mathrm{~mm})$ were cut from the end of 3 point bending test samples to make exact matching. The final size of the bending test samples was $20 * 20 * 350 \mathrm{~mm}$. All the samples were conditioned at $20{ }^{\circ} \mathrm{C}$ and $65 \%$ relative humidity $(\mathrm{RH})$ to achieve around $12 \%$ moisture content (MC). TS 2472 (2005) was used to calculate density.

Equations 1 and 2 were used to calculate MOE and MOR, respectively. Load deformation curves were obtained by performing 3 points bending test using a universal test machine (Marestek, Istanbul, Turkey).

$$
M O E=\frac{\Delta F * L^{3}}{\Delta d * 4 * b * h^{3}}(\mathrm{MPa})
$$

where; $\Delta F$ is the difference between the two loads (F2$\mathrm{F} 1)$ in the linear elastic region, $L$ is the span ( $\mathrm{mm}), \Delta d$ is the deflection (mm), $b$ and $h$ are the width (mm) and thickness $(\mathrm{mm})$ of the sample, respectively.

$$
M O R=\frac{3 * F * L}{2 * b * h^{2}}(\mathrm{MPa})
$$

where; $F$ is the load at failure $(\mathrm{N}), L$ is the span between supports (mm), $b$ and $h$ are the width $(\mathrm{mm})$ and thickness $(\mathrm{mm})$ of the sample, respectively.

EPOCH 650 flaw detector (Olympus, USA) and contact type transducers (Panametrics, USA) were used for US measurement. Also, a coupling agent was used to eliminate noise. Longitudinal ultrasonic wave $(2.25 \mathrm{MHz})$ was propagated through the longitudinal direction of samples to measure transmission time. And, longitudinal ultrasonic wave velocity in the longitudinal direction $\left(\mathrm{V}_{\mathrm{LL}}\right)$ was calculated using transmission time $(\mu \mathrm{s})$ and propagation length (sample size). The $E_{\mathrm{dyn}}$ was calculated using Equation 3 . 
434

$$
E_{d y n}=\rho V_{L L}^{2} 10^{-6}(\mathrm{MPa})
$$

where; $\rho$ is the density of the sample $\left(\mathrm{kg} / \mathrm{m}^{3}\right)$ and $V_{i i}$ is the velocity of US $(\mathrm{m} / \mathrm{s})$.

Pearson correlation coefficients and linear regression models were determined to interpret the relations between the variables.

\section{Results and discussion}

Average values for density, $\mathrm{V}_{\mathrm{LL}}, E_{\mathrm{dyn}}, \mathrm{MOE}$ in bending, and MOR are presented in Table 1, and coefficients of variations were at reasonable levels for all measured properties. As can be seen in Table 1, the densities of the samples were ranged from $0.45 \mathrm{~g} / \mathrm{cm}^{3}\left(210^{\circ} \mathrm{C}\right.$ for $\left.8 \mathrm{~h}\right)$ to 0.48 $\mathrm{g} / \mathrm{cm}^{3}\left(80^{\circ} \mathrm{C}\right.$ Control). Densities were decreased with the increase in duration. However, the decrease in density with the increase in duration is more apparent when the temperature was $210^{\circ} \mathrm{C}$, and around $6.25 \%$ decrease was observed. Density of the unmodified samples are in harmony with reported values $\left(\mathrm{g} / \mathrm{cm}^{3}\right)$ of 0.497 (Efe 2021), 0.502 (Sofuoğlu and Kurtoğlu 2015), 0.510 (Söğütlü 2017), 0.520 (As et al. 2001), 0.523 (Berkel 1951), 0.512 (Demetçi 1986), 0.574 and 0.588 for juvenile and mature wood, respectively (Bal et al. 2012), 0.468 and 0.512 for heart and sapwood wood, respectively (2013), 0.498 (Güntekin and Y1lmaz Aydın 2016), 0.570 (Güntekin et al. 2015a; b; c), 0.53 (Güntekin et al. 2016) and 0.480 to 0.490 (Y1lmaz Aydın and Aydin 2018a).

The average $\mathrm{V}_{\mathrm{LL}}$ of the samples were ranged from 4119 $\mathrm{m} / \mathrm{s}\left(210^{\circ} \mathrm{C}\right.$ for $\left.8 \mathrm{~h}\right)$ to $4720 \mathrm{~m} / \mathrm{s}\left(120^{\circ} \mathrm{C}\right.$ for $\left.8 \mathrm{~h}\right)$. Some increases in velocity were observed at moderate temperatures up to $150^{\circ} \mathrm{C}$. However, the increase in temperature and duration adversely affected the velocity, and around $8.3 \%$ decrease was observed for $210^{\circ} \mathrm{C}$ and $8 \mathrm{~h}$. On the contrary, a maximum $5.96 \%$ increase was obtained when wood was treated at $150^{\circ} \mathrm{C}$ for $2 \mathrm{~h}$. Such a positive effect was also reported by Yilmaz Aydın and Aydın (2018b, 2020) for oak wood. As can be seen in Figure 1, increases or decreases were not stable, indeed, they fluctuated. The same behavior was reported by Yılmaz Aydın and Aydın (2018b) for heat-treated oriental beech. Literature $\mathrm{V}_{\mathrm{LL}}(\mathrm{m} / \mathrm{s})$ values for Taurus cedar were 3332 to 3780 (Yılmaz Aydın and Aydın 2018a), 4388 (Güntekin et al. 2015b; c), and 4510 (Güntekin and Y1lmaz Aydın 2016). It can be said that $\mathrm{V}_{\mathrm{LL}}$ generally agree with the literature.

The average $E_{\mathrm{dyn}}$ of the samples were ranged from 7744 $\mathrm{MPa}\left(210^{\circ} \mathrm{C}\right.$ for $\left.8 \mathrm{~h}\right)$ to $10573 \mathrm{MPa}\left(80^{\circ} \mathrm{C}\right.$ for $\left.8 \mathrm{~h}\right)$. At relatively low temperatures, some increases (up to $10.32 \%$ at $150^{\circ}$ for $2 \mathrm{~h}$ ) were obtained with the increase in duration. However, intensive treatments caused remarkable decreases (21.25\% at $210^{\circ}$ for $8 \mathrm{~h}$ ). Yilmaz Aydın and Aydın (2018b) stated that the effect of treatment became more pronounced when duration increased at $180^{\circ} \mathrm{C}$ and particularly at $210^{\circ} \mathrm{C}$. Reported $E_{\mathrm{dyn}}$ values predicted by US for untreated Taurus cedar were 10929 (Güntekin et al. 2015b; c), and 10137 (Güntekin and Yılmaz Aydın 2016), and it's seen that results of this study conform to literature.

The average MOE in bending values of the samples were varied from $7731 \mathrm{MPa}\left(150^{\circ} 0 \mathrm{~h}\right)$ to $9042 \mathrm{MPa}\left(80^{\circ} \mathrm{C} 8 \mathrm{~h}\right)$. The MOE values were increased with the increase in duration at 80 and $120^{\circ} \mathrm{C}$ while were decreased at 180 and $210^{\circ} \mathrm{C}$. The maximum increase and decrease percentages were $15.27 \%$ $\left(80^{\circ} \mathrm{C} 8 \mathrm{~h}\right)$ and $18.43 \%\left(210^{\circ} \mathrm{C} 8 \mathrm{~h}\right)$, respectively. Increase and then decreases were observed at $150^{\circ} \mathrm{C}$. Average MOE of the unmodified samples are in harmony with reported values (MPa) of 7326 (As et al. 2001), 6668 and 8963 for juvenile and mature wood, respectively (Bal et al. 2012), 7184 (Demetçi 1986), 7803 (Keskin 2001), 8069 (Efe 2021), 9767 (Güntekin and Yılmaz Aydın 2016), 9200 (by compression test-CT) (Güntekin et al. 2016), and 7496 (by CT) (Güntekin et al. 2015b; c).

Average MOR values were ranged from $64.68 \mathrm{MPa}$ $\left(150^{\circ} \mathrm{C}\right.$ for $\left.8 \mathrm{~h}\right)$ to $85.28 \mathrm{MPa}\left(80^{\circ} \mathrm{C}\right.$ for $\left.8 \mathrm{~h}\right)$. MOR values were steadily increased with the increase in duration at 80 and $120^{\circ} \mathrm{C}$ treatments. But, MOR was significantly decreased with the increase in temperature and duration. Among all, MOR was the most affected properties by around $25.14 \%$ decrease at $210^{\circ} \mathrm{C}$ for $8 \mathrm{~h}$ treatment. Average MOR of the unmodified samples are in harmony with reported values (MPa) 77 (As et al. 2001), 75.32 (Öktem and Sözen 1992; Şenel 1994), 75.8 and 94.4 for juvenile and mature wood, respectively (Bal et al. 2012), 86.8 (Keskin 2001), 75.2 (Berkel 1951), 94.3 (Efe 2021), and 91 (Güntekin and Y1lmaz Aydın 2016).

Table 1. Average values of the density, $\mathrm{V}_{\mathrm{LL}}, \mathrm{E}_{\mathrm{dyn}}, \mathrm{MOE}$ in bending, and MOR

\begin{tabular}{|c|c|c|c|c|c|c|}
\hline $\begin{array}{l}\text { Temp. } \\
{\left[{ }^{\circ} \mathrm{C}\right]}\end{array}$ & $\begin{array}{l}\text { Exposure } \\
\text { [Hours] }\end{array}$ & $\begin{array}{l}\text { Density } \\
{\left[\mathrm{g} / \mathrm{cm}^{3}\right]}\end{array}$ & $\frac{\mathrm{V}_{\mathrm{LL}}[\mathrm{m} / \mathrm{s}]}{\text { Mean }(\mathrm{CoV})}$ & $\begin{array}{c}\mathrm{E}_{\mathrm{dyn}}[\mathrm{MPa}] \\
\text { Mean }(\mathrm{CoV})\end{array}$ & $\begin{array}{l}\text { MOE [MPa] } \\
\text { Mean }(\mathrm{CoV})\end{array}$ & $\begin{array}{l}\text { MOR }[\mathrm{MPa}] \\
\text { Mean }(\mathrm{CoV})\end{array}$ \\
\hline 80 & 0 & 0.48 & $4486.22(5.88)$ & $9868.38(11.01)$ & $7843.88(7.66)$ & $76.22(5.26)$ \\
\hline 80 & 2 & 0.48 & $4418.64(3.78)$ & $9491.31(5.99)$ & $8132.97(6.15)$ & $81.12(7.32)$ \\
\hline 80 & 5 & 0.48 & $4554.95(6.14)$ & $9899.68(8.22)$ & $8531.08(8.20)$ & $82.59(4.58)$ \\
\hline 80 & 8 & 0.47 & $4676.30(2.75)$ & $10572.88(6.24)$ & $9041.53(6.03)$ & $85.28(6.21)$ \\
\hline 120 & 0 & 0.46 & $4641.56(4.93)$ & $10016.83(11.19)$ & 8319.11 (11.92) & $80.45(4.93)$ \\
\hline 120 & 2 & 0.46 & 4658.19 (4.69) & $10150.58(6.40)$ & $8619.11(7.40)$ & $82.54(6.97)$ \\
\hline 120 & 5 & 0.45 & $4653.73(5.49)$ & $9920.54(7.65)$ & $8703.05(6.71)$ & $82.70(9.23)$ \\
\hline 120 & 8 & 0.45 & $4720.07(4.82)$ & $10147.74(6.11)$ & $8924.44(4.56)$ & $85.01(8.92)$ \\
\hline 150 & 0 & 0.46 & $4340.75(5.03)$ & $8791.88(8.65)$ & $7731.76(6.83)$ & $72.62(5.03)$ \\
\hline 150 & 2 & 0.45 & $4599.45(7.10)$ & $9698.93(12.13)$ & 8393.63 (12.59) & $68.56(5.64)$ \\
\hline 150 & 5 & 0.45 & $4546.25(7.03)$ & $9450.42(9.99)$ & $8220.00(8.56)$ & $66.40(10.43)$ \\
\hline 150 & 8 & 0.45 & $4507.75(5.29)$ & $9143.5(12.01)$ & $7979.48(8.88)$ & $64.68(9.27)$ \\
\hline 180 & 0 & 0.47 & $4604.58(5.06)$ & $10037.48(8.94)$ & $8416.18(10.48)$ & $84.39(5.05)$ \\
\hline 180 & 2 & 0.46 & $4558.12(5.84)$ & $9714.96(8.35)$ & $8345.58(7.79)$ & $80.38(8.1)$ \\
\hline 180 & 5 & 0.46 & $4499.82(5.38)$ & $9418.76(8.52)$ & $8174.04(8.33)$ & $75.62(6.20)$ \\
\hline 180 & 8 & 0.45 & $4528.53(3.05)$ & $9340.22(6.39)$ & $7988.73(6.30)$ & $71.81(7.68)$ \\
\hline 210 & 0 & 0.48 & $4491.78(3.66)$ & $9833.99(6.23)$ & $8110.04(6.65)$ & $83.46(7.28)$ \\
\hline 210 & 2 & 0.47 & $4408.67(4.31)$ & $9212.26(6.09)$ & $7754.312(6.82)$ & $78.31(9.60)$ \\
\hline 210 & 5 & 0.46 & $4389.29(3.24)$ & $8897.20(6.73)$ & $7509.168(8.13)$ & $68.47(5.74)$ \\
\hline 210 & 8 & 0.45 & $4119.18(5.11)$ & $7743.96(6.93)$ & $6615.54(8.50)$ & $62.48(6.16)$ \\
\hline
\end{tabular}


As illustrated in figure 1, increases and decreases occurred within the groups. However, stable increases or decreases were not observed within and between the groups. Indeed, values fluctuated between the groups. But, MOE and MOR were steadily increased within the groups of 80 and $120^{\circ} \mathrm{C}$. Therefore, treatment using such temperatures provides higher MOE and MOR for Taurus cedar. Furthermore, all the properties were significantly decreased with the increase in exposure duration at 180 and particularly at $210{ }^{\circ} \mathrm{C}$. Sözbir et al. (2019) stated that MOE and MOR were negatively affected by the increase in temperature (120, 160 , and $200^{\circ} \mathrm{C}$ for 1 and $3 \mathrm{~h}$ ). Esteves et al. (2008) expressed that the effect of heat treatment $\left(170-200^{\circ} \mathrm{C}\right.$ for 2 and $\left.24 \mathrm{~h}\right)$ is more pronounced in MOR than MOE for maritime pine. As seen in the results, thermal treatment at relatively low temperature and durations provide more advances for MOE than MOR, but, when temperature and duration were increased MOR was affected more adversely than MOE. Consequently, the results of this study agree with this conclusion.

As in this study, Esteves and Pereira (2009) reported that the influences of heat-treatment on MOE are limited but static and dynamic MOR decreased with the process. The degradation of hemicelluloses (can be affected even at low temperatures) is assumed as the dominant factor for the decreases in mechanical strength. Furthermore, another essential factor might be the crystallization of amorphous cellulose. On the contrary, cross-linking process due to the poly-condensation reaction of lignin positively influenced the longitudinal properties.
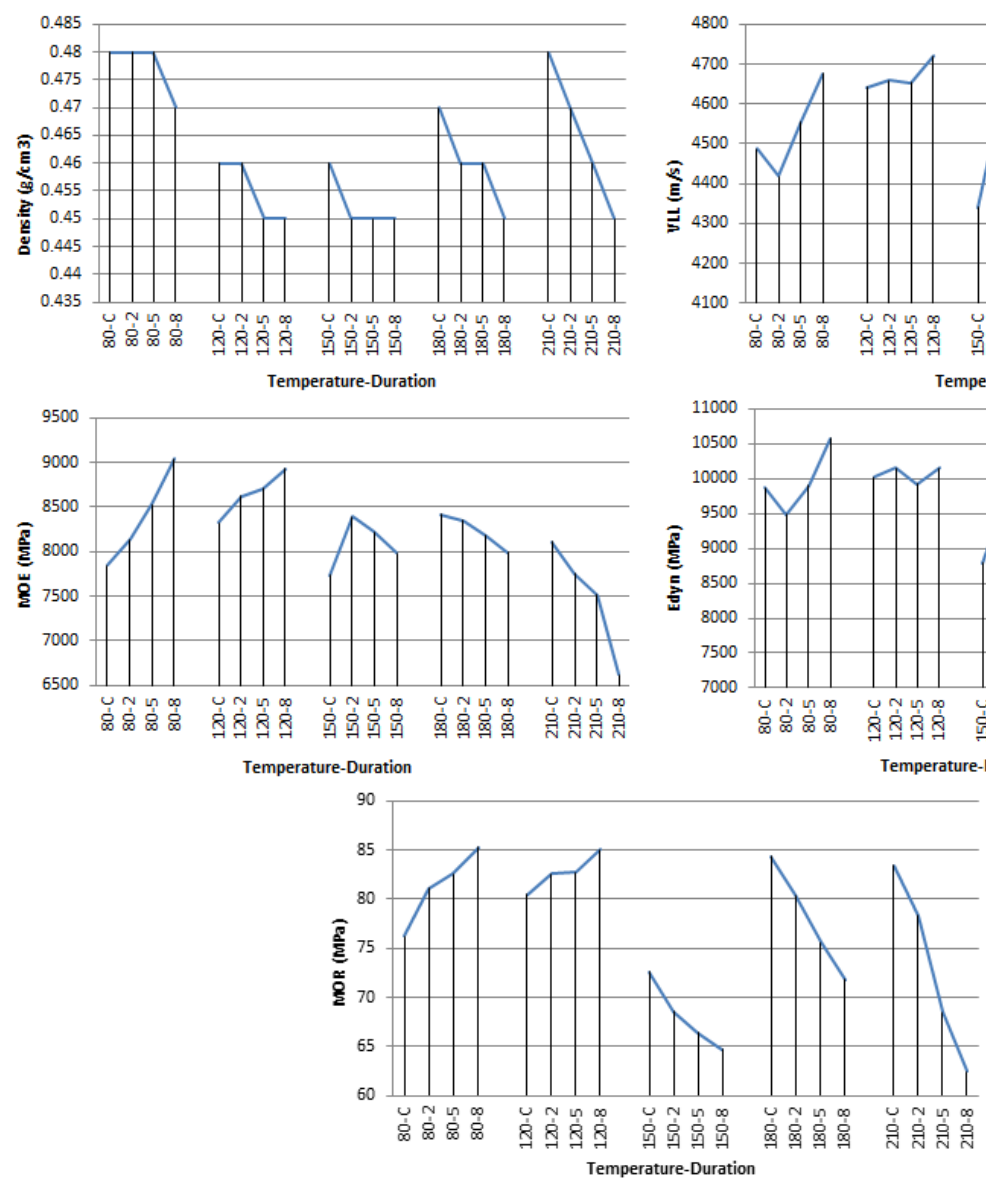

Figure 1. Property changes in terms of treatment groups
Sahin Kol et al. (2017) stated that an increase in temperature (up to $212^{\circ} \mathrm{C}$ ) caused gradual decreases in MOR for beech. On the contrary, MOE reached its maximum level at $180{ }^{\circ} \mathrm{C}$ and then decreased with the increase in temperature but was not lower than the control value. Perçin et al. (2016) stated that MOR and MOE in bending of beech were increased when heat treatment was performed at $150{ }^{\circ} \mathrm{C}$ for 1 and $3 \mathrm{~h}$. However, these properties were decreased further temperature applications. Yang et al. (2016) evaluated the effect of temperature $\left(170,190\right.$, and $\left.210^{\circ} \mathrm{C}\right)$ and duration (1, 2, and4 h) on MOR and MOE of Japanese cedar, and stated that values were decreased with the increase in temperature and duration. However, as in this study, some fluctuations were observed while temperature and duration increased.

It's known that ultrasonically determined mechanical values are generally higher than values those of statically determined. When compared to static results, an overestimation of MOE is the fact when using US, and differences were more pronounced in the wood species that has diffuse-porous structures (Borůvka et al. 2020). As seen in Table 1, dynamic values were higher than static values for all treatment groups. Numerical differences between $E_{\text {dyn }}$ and MOE in bending were varied from $12.06 \%\left(120^{\circ} \mathrm{C} 8 \mathrm{~h}\right)$ to $20.52 \%\left(80^{\circ} \mathrm{C}\right.$ Control). As in this study, significant differences between $E_{\text {dyn }}$ (US $-54 \mathrm{kHz}$ ) and static MOE in bending for thermally treated $\left(130{ }^{\circ} \mathrm{C}\right.$ and $0.2 \mathrm{MPa}$ for $3 \mathrm{~h}$ in an autoclave and $160^{\circ} \mathrm{C}$ for $3 \mathrm{~h}$ in a kiln) Eucalyptus grandis were reported by Missio et al. (2013).
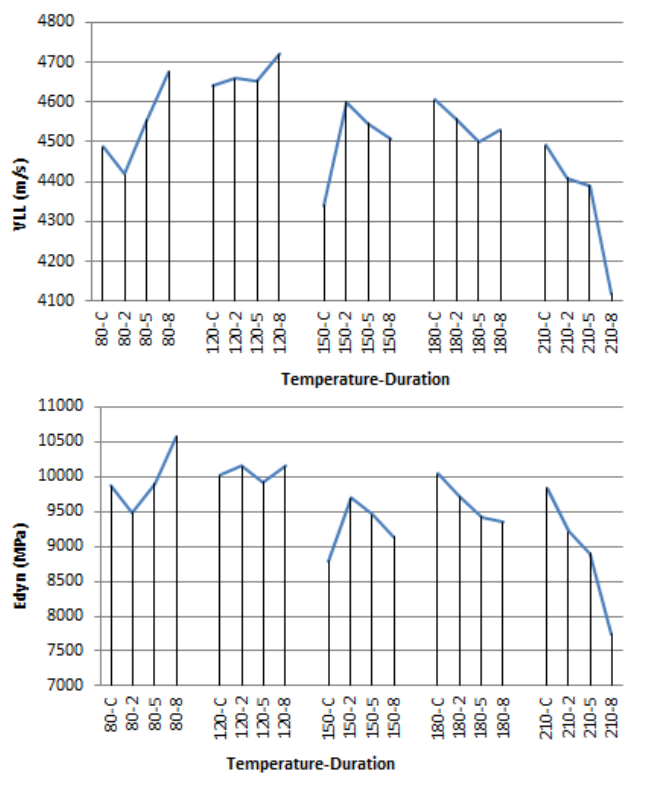
Pearson correlation coefficients are presented in Table 2. As can be seen in the table, almost no linear dependency between the MOR vs $\mathrm{V}_{\mathrm{LL}}$ for 180 and $210^{\circ}$ 8h values were calculated. Apart from those of coefficients, there are moderate and strong relationships between the treatmentinfluenced variables.

Linear regression models and coefficients of determination $\left(\mathrm{R}^{2}\right)$ are presented in Figures 2 to 4 . As can be seen in figure 2 , around $83 \%$ of the data can be reliably predicted using the linear regression model for $\mathrm{E}_{\mathrm{dyn}} \mathrm{vs} \mathrm{MOE}$. But, such a strong relationship was not obtained between $\mathrm{E}_{\mathrm{dyn}}$ vs $\mathrm{MOR}\left(\mathrm{R}^{2}: 0.38\right)$ and MOE vs MOR $\left(\mathrm{R}^{2}: 0.37\right)$. However, highly significant correlations between $\mathrm{MOR}$ and $\mathrm{E}_{\mathrm{dyn}}$ (determined by resonance frequency), and MOR and static MOE of heat-treated $\left(180^{\circ} \mathrm{C}\right.$ for 12 and $24 \mathrm{~h}$, and $210^{\circ} \mathrm{C}$ for 3 and $6 \mathrm{~h})$ red pine (0.76 and 0.81$)$ and larch (0.58 and 0.83$)$ woods were reported by Won et al. (2015).

Such strong relationships between the ultrasonically determined $\mathrm{E}_{\mathrm{dyn}}$ and MOE in bending for heat-treated woods were reported by Yılmaz Aydın and Aydın (2018b) for oriental beech ( $\mathrm{R}^{2}: 075$ to 0.82), Yilmaz Aydın (2020) for oak wood ( $\mathrm{R}^{2}$ : 0.75 to 0.89 ), and Holeček et al. (2016) for Norway spruce $\left(\mathrm{R}^{2}: 0.91\right.$ to 0.92$)$. Furthermore, the $\mathrm{R}^{2}$ between $\mathrm{E}_{\mathrm{dyn}}$ and MOE (Young's modulus) determined by US and compression test were reported by Güntekin et al. (2015a; b) for Taurus cedar $\left(\mathrm{R}^{2}: 0.95\right)$, and Yilmaz Aydın and Aydin (2017) for oriental beech ( $\mathrm{R}^{2}: 0.84$ to 0.94$)$.

Güntekin and Yilmaz Aydın (2016) reported 0.66 and $0.54 \mathrm{R}^{2}$ values for MOE in bending vs MOR and $\mathrm{E}_{\mathrm{dyn}}$ (US $2.25 \mathrm{MHz}$ ) and MOR of Taurus cedar, respectively. The authors conclude that $\mathrm{R}^{2}$ values were lower than other nondestructive test techniques such as stress wave and vibration. Yilmaz Aydın and Aydın (2018a; b; c) reported 0.84 to $0.89,0.64$, and 0.77 to $0.91 \mathrm{R}^{2}$ values reported between the density and $\mathrm{V}_{\mathrm{LL}}$ for Taurus cedar, oriental beech, and oak woods, respectively.

Table 2. Pearson correlation coefficients (r) between variables

\begin{tabular}{|c|c|c|c|c|c|c|c|}
\hline Temp. $\left[{ }^{\circ} \mathrm{C}\right]$ & Exposure [Hours] & $E_{\mathrm{dyn}}-\mathrm{MOE}$ & $E_{\mathrm{dyn}}-\mathrm{MOR}$ & $E_{\mathrm{dyn}}-\mathrm{V}_{\mathrm{LL}}$ & MOE-MOR & MOE- $V_{L L}$ & MOR- $V_{L L}$ \\
\hline 80 & 0 & 0.84 & 0.62 & 0.82 & 0.82 & 0.81 & 0.71 \\
\hline 80 & 2 & 0.80 & 0.72 & 0.65 & 0.87 & 0.55 & 0.41 \\
\hline 80 & 5 & 0.78 & 0.58 & 0.78 & 0.70 & 0.63 & 0.54 \\
\hline 80 & 8 & 0.77 & 0.73 & 0.69 & 0.64 & 0.58 & 0.42 \\
\hline 120 & 0 & 0.94 & 0.67 & 0.59 & 0.73 & 0.58 & 0.22 \\
\hline 120 & 2 & 0.86 & 0.52 & 0.67 & 0.61 & 0.63 & 0.17 \\
\hline 120 & 5 & 0.77 & 0.27 & 0.70 & 0.47 & 0.72 & 0.27 \\
\hline 120 & 8 & 0.82 & 0.52 & 0.56 & 0.67 & 0.33 & 0.26 \\
\hline 150 & 0 & 0.85 & 0.66 & 0.69 & 0.80 & 0.60 & 0.61 \\
\hline 150 & 2 & 0.87 & 0.52 & 0.70 & 0.59 & 0.67 & 0.45 \\
\hline 150 & 5 & 0.79 & 0.61 & 0.74 & 0.77 & 0.56 & 0.33 \\
\hline 150 & 8 & 0.81 & 0.47 & 0.66 & 0.60 & 0.55 & 0.28 \\
\hline 180 & 0 & 0.91 & 0.88 & 0.52 & 0.86 & 0.39 & 0.41 \\
\hline 180 & 2 & 0.71 & 0.42 & 0.67 & 0.77 & 0.49 & 0.18 \\
\hline 180 & 5 & 0.83 & 0.67 & 0.76 & 0.73 & 0.72 & 0.67 \\
\hline 180 & 8 & 0.70 & 0.32 & 0.32 & 0.38 & 0.29 & 0.01 \\
\hline 210 & 0 & 0.92 & 0.82 & 0.25 & 0.91 & 0.29 & 0.16 \\
\hline 210 & 2 & 0.75 & 0.53 & 0.35 & 0.64 & 0.32 & 0.14 \\
\hline 210 & 5 & 0.68 & 0.24 & 0.62 & 0.57 & 0.61 & 0.48 \\
\hline 210 & 8 & 0.72 & 0.33 & 0.56 & 0.60 & 0.23 & 0.06 \\
\hline
\end{tabular}

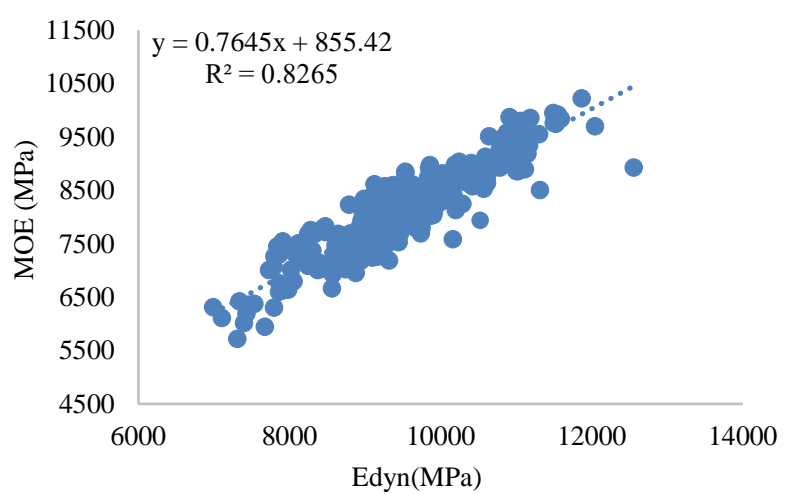

Figure 2. The relationship between $\mathrm{E}_{\mathrm{dyn}}$ and MOE of all species tested

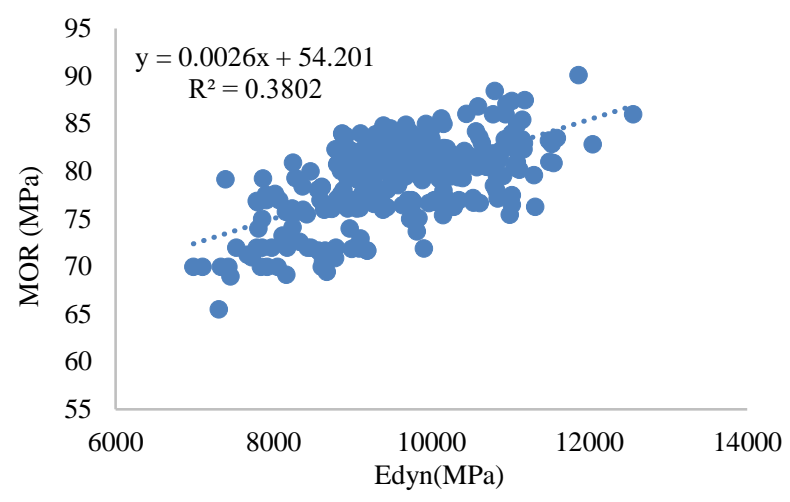

Figure 3. The relationship between $\mathrm{E}_{\mathrm{dyn}}$ and MOR of all species tested 


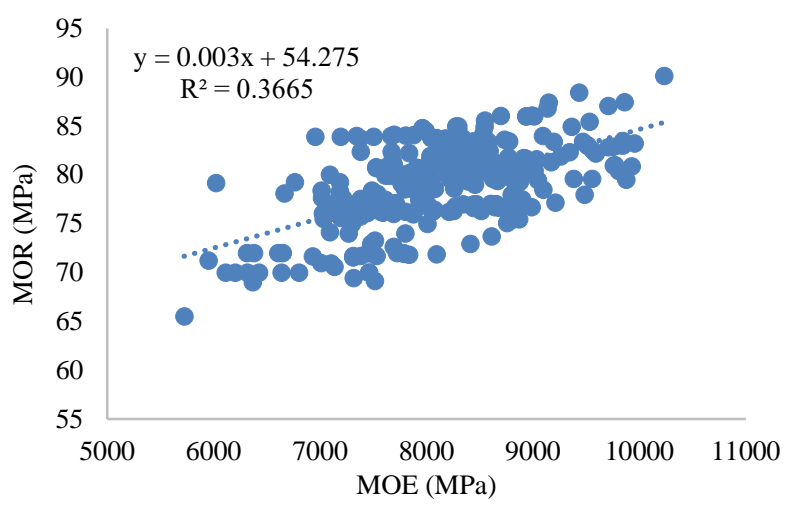

Figure 4. The relationship between MOE and MOR of all species tested

Heat treatment applications, particularly at high temperatures and long exposure duration, cause intense color changes. According to Ünsal et al. (2003) color is one of the major factors in the quality evaluation of wood material that is affected by heat treatment. Therefore, not only mechanical properties should be taken into consideration to perform heattreatment but also aesthetic appearance.

According to Awoyemi and Jones (2011) tracheid walls, ray tissues, and pit de-aspiration were destructed by heat treatment, and besides the chemical degradation which is the major reason for the changes in wood, these anatomical changes are also responsible for the degradation of wood.

Dilik and Hızıroğlu (2012) and Korkut and Hızıroğlu (2013) reported adverse effects of heat-treatment on some properties of Eastern red cedar. According to Bal (2016b) heat treatment has significant influences when the process is performed at moderate temperature levels. The same conclusion was expressed by Yllmaz Aydin (2020). The author stated that some advances can be achieved for the mechanical properties when moderate temperature and durations are used while over $150^{\circ} \mathrm{C}$ applications eliminate these advances.

Higher the MOE, higher the rigidity (Liang and $\mathrm{Fu} 2007$ ), and according to results, $8 \mathrm{~h}$ exposure at 80 and $120^{\circ} \mathrm{C}$ can be used to advance the rigidity of wood.

\section{Conclusion}

In this study, influences of duration and temperature on longitudinal ultrasonic wave velocity, density, $E_{\mathrm{dyn}}$, MOE in bending, and MOR were evaluated. It's shown that MOR was the most affected property by the heat treatment, and followed by $E_{\mathrm{dyn}}$ and $\mathrm{MOE}$ in bending. Up to $150^{\circ} \mathrm{C}$ temperature, increase in exposure duration provided some remarkable advances in mechanical properties and UWV. At some temperature levels, an increase in exposure duration caused oscillations in some values instead of providing stable increases or decreases. A strong relationship was observed between $E_{\mathrm{dyn}}$ and MOE in bending. However, such a strong relationship was not observed between $E_{\mathrm{dyn}}$ and MOR, and MOE in bending and MOR.

It should be considered that there might be differences in the influences of using the constant temperature levels and stepwise heating process on the properties of wood in thermal treatment. Such a study should be performed to figure out this issue.

\section{References}

As, N., Koc, K.H., Doğu, A.D., Atik, C., Aksu, B., Erdinler, E.S., 2001 Türkiye'de yetişen endüstriyel öneme sahip ağaçların anatomik fiziksel, mekanik ve kimyasal özellikleri. Journal of the Faculty of Forestry Istanbul University, 51(1): 71-88.

Awoyemi, L., Jones, I.P., 2011. Anatomical explanations for the changes in properties of western red cedar (Thuja plicata) wood during heat treatment. Wood Science and Technology, 45(2): 261-267.

Ayata, Ü., Bal, B.C., 2019. The effect of heat treatment on Taurus cedar (Cedrus libani A. Rich.) wood exposed to microbiologically active soils. EURO ASIA 4. International Congress on Applied Sciences, September 27-29, Kiev, pp.13-18.

Bal, B.C., 2013. Effects of heat treatment on the physical properties of heartwood and sapwood of Cedrus libani. BioResources, 8, 211219.

Bal, B.C., 2016a. Some physical properties of Taurus fir wood (Abies cilicica) treated with hot vegetable oil. KSU. Journal of Engineering Sciences, 19(2): 20-26.

Bal, B.C., 2016b. Physical properties of beech wood thermally modified in hot oil and in hot air at various temperatures. Maderas Ciencia y Tecnologia, 17(4): 789-798.

Bal, B.C., Bektaş, I., Kaymakçı, A., 2012. Some physical and mechanical properties of juvenile wood and mature wood of Taurus cedar. KSU. Journal of Engineering Sciences, 15(2): 17-26.

Berkel, A., 1951. Lübnan sedirinde teknolojik araştırmalar. IÜ Orman Fakültesi Dergisi, A1(1): 182-211.

Borůvka, V., Novák, D., Šedivka, P., 2020. Comparison and analysis of radial and tangential bending of softwood and hardwood at static and dynamic loading. Forests, 11(8).

Chen, J.H., Wang, S.Y., Lin, C.J., Chiu, C.M., Tsai, M.J., 2014 Evaluation of quality of japanese cedar (Cryptomeria japonica) trees grown under different row thinning treatments. Journal of Tropical Forest Science, 26(2): 275-283.

Chien, Y.C., Yang, T.C., Hung, K.C., Li, C.C., Xu, J. W., Wu, J.H., 2018. Effects of heat treatment on the chemical compositions and thermal decomposition kinetics of Japanese cedar and beech wood. Polymer Degradation and Stability, 158, 220-227.

Chiu, C.M., Lin, C.H., Yang, T.H., 2013. Application of nondestructive methods to evaluate mechanical properties of 32-year-old taiwan incense cedar (Calocedrus formosana) wood. BioResources, 8(1): 688-700.

Chuang, S.T., Wang, S.Y., 2001. Evaluation of standing tree quality of Japanese cedar grown with different spacing using stress-wave and ultrasonic-wave methods. Journal of Wood Science, 47(4): 245253.

Dilik, T., Hiziroglu, S., 2012. Bonding strength of heat treated compressed Eastern redcedar wood. Materials and Design, 42(2012): 317-320.

Efe, F., 2021. A study on the determination of some physical and mechanical properties of wood of Taurus cedar. Turkish Journal of Agricultural and Natural Sciences, 8(1): 43-52.

Esteves, B.M., Domingos, I.J., Pereira, H.M., 2008. Pine wood modification by heat treatment in air. BioResources, 3(1): 142-154.

Esteves, B. M., Pereira, H.M., 2009. Wood modification by heat treatment - A review. Bioresources, 4(1965): 370-404.

Gennari, E., Picchio, R., Monaco, A.Lo., 2021. Industrial heat treatment of wood: Study of induced effects on ayous wood (Triplochiton scleroxylon K. Schum). Forests, 12(6):730.

Güntekin, E., Aydı, T.Y., Niemz, P., 2015a. Prediction of compression properties in three orthotropic directions for some important Turkish wood species using ultrasound. BioResources, 10(4): 7252-7262.

Güntekin, E., Yılmaz Aydın, T., Niemz, P., 2015b. Determination of Young's modulus in three orthotropic directions for Calabrian pine and Taurus cedar using ultrasound and digital image correlation (DIC). 3rd. Int. ISITES, June 3-5, Valecia, pp.42-51.

Güntekin, E., Y1lmaz Aydın, T., Niemz, P., 2015c. Prediction of Young's modulus in three orthotropic directions for some important Turkish wood species using ultrasound. 19th International Nondestructive Testing and Evaluation of Wood Symposium, September 22-25, Forest Products Laboratory, Madison, pp.7-14.

Güntekin, E., Yılmaz Aydın, T., 2016. Prediction of bending properties for some softwood species grown in Turkey using ultrasound. Wood Research, 61(6): 993-1002. 
Güntekin, E., Yılmaz Aydın, T., Aydın, M., 2016. Elastic constants of Calabrian pine and Cedar. International Forestry Symposium, December 7-10, Kastamonu Üniversitesi, Kastamonu, pp.645-649.

Hasegawa, M., Mori, M., Matsumura, J., 2016. Non-contact velocity measurement of Japanese cedar columns using air-coupled ultrasonics. World Journal of Engineering and Technology, 4(1):4550.

Hasegawa, M., Takata, M., Matsumura, J., Oda, K., 2011. Effect of wood properties on within-tree variation in ultrasonic wave velocity in softwood. Ultrasonics, 51(3): 296-302.

Holeček, T., Gašparík, M., Lagaňa, R., Borůvka, V., Oberhofnerová, E., 2016. Measuring the modulus of elasticity of thermally treated Spruce wood using the ultrasound and resonance methods. BioResources, 12(1):819-838.

Keskin, H., 2001. Lamine Masif Ağaç Malzemelerin Teknolojik Özellikleri ve Ağaç İşleri Endüstrisinde Kullanım İmkanları. Doktora Tezi, Gazi Üniversitesi, Fen Bilimleri Enstitüsü, Ankara.

Kılınçarslan, Ş., Şimşek Türker, Y., İnce, M., 2020. Prediction of heattreated cedar wood swelling and shrinkage with artificial neural networks and random forest algorithm. Journal of Engineering Sciences and Design, 8(5): 200-205.

Korkut, S., Hiziroglu, S., 2013. Selected properties of heat-treated Eastern red cedar (Juniperus virginiana L.) Wood. BioResources, 8(2): 4756-4765

Liang, S. Q., Fu, F., 2007. Comparative study on three dynamic modulus of elasticity and static modulus of elasticity for Lodgepole pine lumber. Journal of Forestry Research, 18(4): 309-312.

Missio, A.L., Gatto, D.A., Modes, K.S., Santini, E.J., Stangerlin, D.M., Calegari, L., 2013. Ultrasonic method for estimation of modulus of elasticity of Eucalyptus grandis wood. Revista Brasileirade Ciencias Agrarias, 8(1): 102-107.

Nabil, E., Mahmoud, N., Youssef, A., Saber, E., Kamel, S., 2018. Evaluation of physical, mechanical and chemical properties of Cedar and sycamore woods after heat treatment. Egyptian Journal of Chemistry, 61(6): 1131-1149.

Oh, J.-K., Yeo, H.-M., Choi, I.-G., Lee, J.-J., 2011. Feasibility of ultrasonic log sorting in manufacturing structural lamination from Japanese cedar logs. Journal of the Korean Wood Science and Technology, 39(2): 163-171.

Öktem, E., Sözen, R., 1992. Sedir odununun anatomik ve teknolojik özellikleri ile kullanım yerleri. In: Sedir, (Ed., Eler, Ü.), Ormancilık Araştırma Enstitüsü, Ankara, 287-297.

Perçin, O., Peker, H., Atilgan, A., 2016. The effect of heat treatment on the some physical and mechanical properties of Beech (Fagus orientalis Lipsky) wood. Wood Research, 61(3): 443-456.

Sofuoğlu, S.D., Kurtoğlu, A., 2015. Effects of machining conditions on surface roughness in planing and sanding of solid wood. Drvna industrija, 66(4): 265-272.

Sögütlü, C., 2017. Determination of the effect of surface roughness on the bonding strength of wooden materials. BioResources, 12(1): 1417-1429.

Sözbir, G.D., Bektaş, I., Ak, A.K., 2019. Influence of combined heat treatment and densification on mechanical properties of Poplar wood. Maderas: Ciencia y Tecnologia, 21(3): 481-492.

Şahin Kol, H., Aysal Keskin, S., Gündüz Vaydoğan, K., 2017. Effect of heat treatment on the mechanical properties and dimensional stability of beech wood. Journal of Advanced Technology Sciences, 6(3): $820-830$.
Senalik, C., Schueneman, G., Ross, R., 2014. Ultrasonic-Based Nondestructive Evaluation Methods for Wood a Primer and Historical Review. Madison.

Şenel, A., 1994. Toros sediri (Cedrus libani) ağacının malzeme olarak bazı fiziksel, mekanik ve teknolojik özellikleri. Gazi Üniversitesi, End. San. Eğt. Fak. Der., 2(2): 145-150.

TS 2472, 2005. Wood - Determination of Density for Physical and Mechanical Tests, Wood, sawlogs and sawn timber (ICS 79.040), Ankara.

Ünsal, O., Korkut, S., Atik, C., 2003. THE effect of heat treatment on some properties and colour in Eucalyptus (Eucalyptus camaldulensis DEHN.) wood. Maderas Ciencia y tecnología, 5(2): 145-152.

Wang, S.Y., Chen, J.H., Hsu, K.P., Lin, C.J., Jane, M.C., 2008. Ring characteristics and compressive strength of Japanese cedar trees grown under different silvicultural treatments. Wood and Fiber Science, 40(3): 384-391.

Won, K.R., Hong, N.E., Park, H.M., Moon, S.O., Byeon, H.S., 2015. Effects of heating temperature and time on the mechanical properties of heat-treated woods. Journal of the Korean Wood Science and Technology, 43(2): 168-176.

Yang, T.H., Chang, F.R., Lin, C.J., Chang, F.C., 2016. Effects of temperature and duration of heat treatment on the physical, surface, and mechanical properties of Japanese cedar wood. BioResources, 11(2): 3947-3963.

Yeh, M.C., Liu, C.K., Lin, Y.L., 2007. Effects of ultrasonic detection modes on the longitudinal ultrasonic wave transmission in domestic plantation lumber. Taiwan Journal of Forest Science, 22(1): 57-68.

Yilmaz Aydin, T., 2020. Ultrasonic evaluation of time and temperaturedependent orthotropic compression properties of Oak wood. Journal of Materials Research and Technology, 9(3):6028-6036.

Yılmaz Aydın, T., Aydın, M., 2017. Determination of compression properties in radial direction of Oriental beech exposed to temperature using ultrasound and static tests. 20th International Nondestructive Testing and Evaluation of Wood Symposium, September 12-15, Forest Products Laboratory, Madison, pp.249254.

Y1lmaz Aydın, T., Aydın, M., 2018a. Relationship between density or propagation length and ultrasonic wave velocity in Cedar (Cedrus libani) wood. International Science and Technology Conference, July 18-20, Paris, pp. 531-535.

Yilmaz Aydın, T., Aydın, M., 2018b. Prediction of bending properties of Oriental beech wood exposed to temperature. International Forest Products Congress, September 26-29, Trabzon, pp.772-778.

Yılmaz Aydın, T., Aydın, M., 2018c. Relationship between density or propagation length and ultrasonic wave velocity in Sessile oak (Quercus petraea) wood. 4th Int. Conf. on Advances in Mechanical Enginering, December 19-21, Yıldız Technical University, İstanbul, pp. 1708-1712.

Yilmaz Aydın, T., Aydın, M., 2020. Influence of temperature and exposure duration on the bending properties of Oak wood. Journal of Bartin Faculty of Forestry, 22(3), 871-877. 